\title{
Uji Coba Vaksin Dengue Rekombinan pada Hewan Coba Mencit,Tikus, Kelinci dan Monyet
}

\author{
Soegeng Soegijanto; Fedik A Rantam; Soetjipto, Ketut Sudiana, Yoes Priyatna
}

\begin{abstract}
Pencegahan terhadap infeksi dengue dengan cara vaksinasi perlu dikembangkan; oleh karena secara epidemiologi infeksi virus dengue telah menyebar ke daratan Asia, Afrika, Amerika dan Eropa. Pendekatan pencegahan dan pemberantasan dengan melakukan pemberantasan vektor tidaklah cukup untuk menekan angka kesakitan. Pengembangan vaksin dengan menggunakan protein $\mathrm{E}$ dapat menginduksi produksi antibodi terhadap semua strain (galur) virus dengue.

Tujuan penelitian menentukan daya proteksi antibodi yang dipacu oleh calon vaksin pada hewan percobaan (mencit, tikus, kelinci dan monyet).

Metode penelitian Isolasi virus dari pasien DBD di RS Dr. Sutomo Surabaya dan isolat standar dari NAMRU-2 Jakarta. Dilakukan purifikasi isolat virus dengue dan purifikasi protein E rekombinan. Selanjutnya dilakukan imunisasi pada binatang percobaan dan dinilai respon imunnya.

Hasil penelitian karakterisasi dan identifikasi imunoglobulin dari mencit yang diimunisasi dengan protein E selain IgM, IgG ditentukan subklas IgG1a, IgG2a, IgG2b. Protein E pada hewan percobaan dapat menginduksi antibodi humoral dengan berbagai kelas imunoglobulin maupun subkelasnya dan antibodi seluler yang protektif. Analisis hasil respon imun pada CD 4 dan CD 8 yang di isolasi dari hewan percobaan yang telah diimunisasi, direuksikan dengan IFN- $\partial$ ternyata menunjukkan adanya perbedaan respon imun yang berbeda. Pada challenge test hanya monyet yang memberikan respons patologis yaitu terlihat adanya perdarahan pada hari ke tiga setelah infeksi. Protein E yang diimunisasikan pada monyet dapat menginduksi antibodi humoral dengan titer cukup tinggi terutama imunoglobulin G.
\end{abstract}

Kata kunci: virus dengue, protein E, imunoglobulin, antibodi, vaksin dengue.

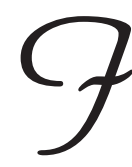

nfeksi virus Dengue dapat digambarkan sebagai pola gunung es yang sebagian besar tidak menunjukkan manifestasi klinik dan disebut sebagai demam dengue yang dapat sembuh sendiri. Demam berdarah dengue secara klinis dikelompokkan DBD (Demam Berdarah Dengue) tanpa syok dan DBD dengan syok. ${ }^{1}$

Alamat korespondensi:

Prof.DR.H. Soegeng Soegijanto, Dr,SpA(K),DTM\&H.

Bagian Ilmu Kesehatan Anak FK-TDC UNAIR RS Dr. Soetomo.

Jl Prof. Dr. Moestopo 6-8, Surabaya 60132.

Telepon: 031-5501680/81, Fax.: 031-5501680.
Perbedaan yang nyata demam berdarah dengue dan demam dengue adalah terjadinya proses keluarnya plasma dari dalam pembuluh darah yang mengalir ke ruang intersisial yang berakibat terjadinya gangguan sirkulasi vaskuler sehingga terjadi syok. Pada saat itu dapat terjadi trombositopenia dan perdarahan. Penderita demam berdarah dengue dengan syok dikenal sebagai sindrom dengue syok atau DSS (dengue shock syndrome). ${ }^{2}$

Di Indonesia outbreak virus Dengue terjadi setiap lima tahun sehingga dikenal dengan kasus lima tahunan $^{3}$, tetapi dalam dekade terakhir ini terlihat bahwa virus ini tidak hanya terjadi setiap lima tahun 
dan tidak hanya terjadi pada anak tetapi juga pada orang dewasa. ${ }^{4}$ Pendekatan pencegahan dan pemberantasan DBD di Indonesia sampai saat ini adalah melakukan pemberantasan vektor dengan cara membasmi nyamuk di daerah endemik. Hal ini tidak dapat menekan angka kesakitan secara tuntas oleh karena itu pendekatan dengan cara vaksinasi merupakan alternatif yang tepat dalam pengendalian penyakit DBD di Indonesia

\section{Pokok Permasalahan Penelitian}

Protein E mempunyai sifat yang sempurna sebagai vaksin karena dapat mengenali semua galur virus Dengue yang didukung dengan berat molekulnya, walaupun demikian masih memerlukan pembawa sebagai imunomodulator yang dapat menstimulasi sel B dan sel Th untuk menginduksi produksi antibodi melalui ekspresi sitokin, sehingga titer antibodi semakin tinggi. Protein E mempunyai sifat hidrofobik yang tinggi, banyak mengandung histidin dan sifatnya stabil. Oleh karena itu telah dikembangkan protein $\mathrm{E}$ hasil rekombinan dengan baculovirus yang kemudian digunakan sebagai bahan vaksin klon subunit. Epitop dari protein E mengandung banyak asam amino yang merangsang terbentuknya antibodi neutralisasi yang dibentuk melalui proses acidic compartments yang disekresikan lewat komplek golgi. Karakterisasi E protein yang dikode DNA dari semua galur telah disekresi melalui sel jaringan dan secara invivo mempunyai sifat reaktivitas yang tinggi dan tingkat imunogenitas yang optimal sebagai vaksin klon - subunit. ${ }^{5}$ Model ekspresi dengan baculovirus akan didapatkan protein yang stabil dan bersifat seperti partikel virus, sehingga ideal untuk dikembangkan sebagai vaksin dengue yang multivalen.

\section{Tujuan Penelitian}

\section{Tujuan umum}

Memanfaatkan protein E virus Dengue secara rekombinan untuk pengembangan vaksin klon subunit dengan menggunakan baculovirus yang dimodifikasi, sehingga dapat memacu antibodi protektif untuk semua galur.

\section{Tujuan khusus}

Menentukan daya proteksi antibodi yang dipacu oleh calon vaksin pada hewan percobaan (mencit, tikus, kelinci dan monyet).

\section{Metode Penelitian}

Isolasi virus didapat dari pasien DBD di RS Dr. Sutomo Surabaya dan isolat standar diperoleh dari NAMRU-2 Jakarta. Dilakukan purifikasi isolat virus dengue dan purifikasi protein E rekombinan. Selanjutnya dilakukan imunisasi pada binatang percobaan dan dinilai respon imunnya.

\section{Virus dan Isolasi}

Sampel virus merupakan hasil isolasi dari pasien DBD yang di rawat di RS Dr. Soetomo Surabaya yang merupakan isolat Lab. Dengue TDC-Unair dan isolat standard dari NAMRU-2 Jakarta . Virus ini diisolasi dengan menggunakan sel C6/36 p27 berasal dari NAMRU-2 Jakarta.

\section{Serum}

Koleksi sampel serum diambil dari pasien DBD dengan derajat sakit yang berbeda mulai dari yang ringan sampai berat. Pengumpulan sampel serum ini dilakukan sejak tahun 1997. Selanjutnya dilakukan purifikasi isolat virus dengue dan semi nested-PCR (s$n$-Polymerase Chain Reaction), analisis DNA dan RNA, karakterisasi genom galur virus dengue dan genom protein E, karakterisasi protein E, SDS-PAGE (Sodium Deodocyl Sulphat Polyacrylamid Gel-electrophoresis) dan purifikasi protein E rekombinan.

Selanjutnya dilakukan perlakuan:

a. Imunisasi mencit dan analisis respon imun.

b. Enzyme-linked immunosorbent assay (ELISA)

c. Deteksi sitokin intraselular

d. Challenge test

\section{Hasil Penelitian}

Karakterisasi dan identifikasi imunoglobulin dari mencit yang diimunisasi dengan protein E selain IgM, IgG ditentukan subklas IgG1a, IgG2a, IgG2b. Protein 
E pada hewan percobaan dapat menginduksi antibodi humoral dengan berbagai kelas imunoglobulin maupun subkelasnya dan antibodi selular yang protektif. Analisis hasil respon imun pada CD 4 dan CD 8 yang di isolasi dari hewan percobaan yang telah diimunisasi, direaksikan dengan IFN- $\gamma$ ternyata menunjukkan adanya perbedaan respon imun yang berbeda. Pada challenge test hanya monyet yang memberikan respons patologis yaitu terlihat adanya perdarahan pada hari ke tiga setelah infeksi. Protein E yang diimunisasikan pada monyet dapat menginduksi antibodi humoral dengan titer cukup tinggi terutama imunoglobulin G.

\section{Analisis titer antibodi pada mencit}

Pada Tabel 1 terlihat rata-rata titer antibodi dari mencit yang diimunisasi dengan protein E. Imunisasi dengan doses $20 \mathrm{mg}$ menghasilkan respon antibodi yang lebih tinggi dibandingkan dengan dosis $10 \mathrm{mg}$, dan stimulasi antibodi yang ditimbulkan cukup tinggi jika dibandingkan dengan kontrol negatif dan terlihat rata-rata titer antibodi lebih besar 5,3 sehingga presentasi

\section{Analisis respon imun CD4 dan CD8 sel T}

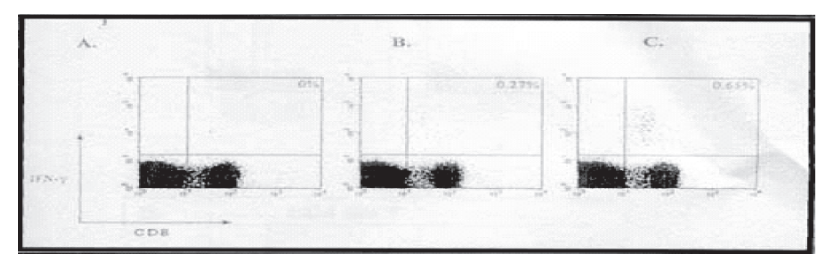

Gambar 1. Analisis CD8 spesifik epitope pada sellimfosit dari darah perifer

Keterangan:

A) Analisis CD8 dari mencit yang diimunisasi dengan PBS hari ke 10, 21 dan 28 setelah imunisasi.

B) Analisis CD8 dari mencit yang diimunisasi dengan protein E $500 \mathrm{mg} / \mathrm{ml}$

C) Dosis imunisasi $1 \mathrm{mg} / \mathrm{ml}$ hari ke 0, 12 dan ke 28 setelah imunisasi konsentrasi CD8 positif sekitar $0,27 \%$ (dosis $500 \mathrm{mg}$ ) dan $0,65 \%$ (dosis $1 \mathrm{mg}$ ) yang dianalisis dengan FAC Scalibur flow cytometer.

\section{Challenge test imunisasi mencit dengan protein $\mathrm{E}$ (Tabel 2,3,4)}

Tabel 1. Analisis titer antibodi spesifik protein E rekombinan

\begin{tabular}{cccccc}
\hline \multicolumn{5}{c}{ ELISA Titer Antibodi $(\log 2$ of dilution) } \\
\hline \multicolumn{7}{c}{ Inokulasi pertama Inokulasi ke dua } \\
\hline Protein E & Jumlah mencit & Rerata & Prosentase & Rerata & Prosentase \\
\hline $10 \mathrm{mg}$ & 10 & 16.6 & 100 & 19.6 & 100 \\
$20 \mathrm{mg}$ & 10 & 18.9 & 100 & 20.6 & 100 \\
Kontrol & 10 & 0.01 & 100 & 0.01 & 100 \\
\hline
\end{tabular}

didalam tabel diatas tertulis semua $100 \%$.

Pada hewan percobaan selain dianalisis respon imun humoral melalui titer imunoglobulin juga respon imun selulernya dengan cara flowcytometri. Data dapat dilihat pada Gambar 1.
Respon antibodi pada mencit yang diimunisasi dengan protein E rekombinan dan selanjutnya diinjeksi campuran virus dengue (DEN1-4) sebagai challenge test.

Tabel 2. Titer antibodi dari mencit yang di challenge test

\begin{tabular}{cccccc}
\hline \multicolumn{5}{c}{ Resiprokal Titer Antibodi Neutralisasi } \\
\hline Protein E & Jumlah Mencit & $\begin{array}{c}\text { Infeksi } \\
\text { Ke 1 }\end{array}$ & $\begin{array}{c}\text { Infeksi } \\
\text { Ke 2 }\end{array}$ & $\begin{array}{c}\text { Infeksi } \\
\text { Ke 3 }\end{array}$ & Viremia \\
\hline $20 \mu \mathrm{g}$ & 10 & 40 & 200 & 380 & 0 \\
$10 \mu \mathrm{g}$ & 10 & $<10$ & 60 & 280 & 0 \\
Kontrol & 10 & $<10$ & $<10$ & 0 & 10 \\
\hline
\end{tabular}

Keterangan

- $0=$ tidak ada viremia

- Titer virus pada kontrol mencit 1-10:180, 220, 200, 180, 220, 80, 80, 200, 60, $60 \mathrm{FFU} / \mathrm{ml}$ (focus forming unit). 
Sari Pediatri, Vol. 5, No. 2, September 2003

\section{Profil imunoglobulin pada tikus}

Tabel 3. Titer antibodi dari tikus yang di challenge test

\begin{tabular}{|c|c|c|c|c|c|}
\hline Group & Imunisasi & $\begin{array}{l}\text { Klas dan subklas } \\
\text { imunoglobulin }\end{array}$ & $\mathrm{n}$ & Hari ke 14 & Hari ke 28 \\
\hline \multirow[t]{5}{*}{1} & i.m & $\operatorname{IgM}$ & 10 & + & - \\
\hline & $(20 \mathrm{mg})$ & IgG & 10 & + & +++ \\
\hline & & $\operatorname{IgG} 1 \mathrm{a}$ & 10 & + & + \\
\hline & & $\operatorname{IgG} 2 \mathrm{a}$ & 10 & + & + \\
\hline & & $\operatorname{IgG} 2 b$ & 10 & + & ++ \\
\hline \multirow[t]{5}{*}{2} & i.m & IgM & 10 & + & - \\
\hline & $(40 \mathrm{mg})$ & $\mathrm{IgG}$ & 10 & + & +++ \\
\hline & & $\operatorname{IgG} 1 \mathrm{a}$ & 10 & + & + \\
\hline & & $\operatorname{IgG} 2 \mathrm{a}$ & 10 & + & + \\
\hline & & $\operatorname{IgG} 2 b$ & 10 & + & +++ \\
\hline \multirow[t]{5}{*}{3} & i.m & IgGM & 10 & - & - \\
\hline & (1 $\mathrm{ml}$ PBS) & $\mathrm{IgG}$ & 10 & - & - \\
\hline & & IgGla & 10 & - & - \\
\hline & & $\mathrm{IgG} 2 \mathrm{a}$ & 10 & - & - \\
\hline & & IgG2b & 10 & - & -- \\
\hline
\end{tabular}

\section{Profil antibodi pada kelinci}

Tabel 4. Titer antibodi dari kelinci yang di challenge test

\begin{tabular}{|c|c|c|c|c|c|}
\hline Group & Imunisasi & $\begin{array}{l}\text { Klas dan subklas } \\
\text { imunoglobulin }\end{array}$ & $\mathrm{n}$ & Hari ke 14 & Hari ke 28 \\
\hline \multirow[t]{5}{*}{1} & i.m & $\operatorname{IgM}$ & 7 & + & - \\
\hline & $(40 \mathrm{mg})$ & $\mathrm{IgG}$ & 7 & + & +++ \\
\hline & & IgG1a & 7 & + & ++ \\
\hline & & $\operatorname{IgG} 2 \mathrm{a}$ & 7 & + & + \\
\hline & & IgG2b & 7 & + & ++ \\
\hline \multirow[t]{5}{*}{2} & i.m & IgM & 7 & + & - \\
\hline & $(50 \mathrm{mg})$ & $\mathrm{IgG}$ & 7 & + & +++ \\
\hline & & $\operatorname{IgG} 1 \mathrm{a}$ & 7 & + & +++ \\
\hline & & $\operatorname{IgG} 2 \mathrm{a}$ & 7 & + & ++ \\
\hline & & $\mathrm{IgG} 2 \mathrm{~b}$ & 7 & + & +++ \\
\hline \multirow[t]{5}{*}{3} & i.m & IgM & 7 & - & - \\
\hline & $(1 \mathrm{ml} \mathrm{PBS})$ & IgG & 7 & - & - \\
\hline & & $\operatorname{IgG1a}$ & 7 & - & - \\
\hline & & $\operatorname{IgG} 2 \mathrm{a}$ & 7 & - & - \\
\hline & & $\operatorname{IgG} 2 b$ & 7 & - & - \\
\hline
\end{tabular}


Sari Pediatri, Vol. 5, No. 2, September 2003

\section{Imunisasi monyet (macaca fasicularis) dengan protein $\mathrm{E}$}

Tabel 5. Titer antibody dari monyet yang di challenge test

\begin{tabular}{lllll}
\hline \multicolumn{4}{c}{ Resiprokal titer Antibodi Neutralisasi } \\
\hline Protein E (dosis) & Monyet & Imunisasi 1 & Imunisasi 2 & Imunisasi 3 \\
\hline Kontrol & 2 & & & \\
$($ PBS 1 ml) & MF 1 & $<10$ & $<10$ & $<10$ \\
& MF 2 & $<10$ & $<10$ & $<10$ \\
Perlakuan & 4 & & & \\
$(1$ mg) & MF 3 & 40 & 280 & 460 \\
& MF 4 & 40 & 280 & 460 \\
& MF 5 & 20 & 180 & 280 \\
& MF 6 & 40 & 280 & 480 \\
\hline
\end{tabular}

\section{Uji tantang (Challenge test) macaca fasicularis dengan virus DEN-1, 2, 3, 4}

Tabel 6. Titer antibodi dan viremia virus DEN dari monyet yang di challenge test

\begin{tabular}{lllllll}
\hline \multicolumn{7}{l}{ Resiprokal Titer Antibodi Neutralisasi } \\
\hline $\begin{array}{l}\text { Protein E } \\
\text { (dosis) }\end{array}$ & Monyet & $\begin{array}{l}\text { Infeksi } \\
\text { DEN-1 }\end{array}$ & $\begin{array}{l}\text { Infeksi } \\
\text { DEN-2 }\end{array}$ & $\begin{array}{l}\text { Infeksi } \\
\text { DEN-3 }\end{array}$ & $\begin{array}{l}\text { Infeksi } \\
\text { DEN-4 }\end{array}$ & Viremia \\
\hline Kontrol & MF 1 & 20 & 40 & 40 & 20 & 220 \\
(PBS 1 ml) & MF 2 & 20 & 20 & 40 & 20 & 220 \\
Perlakuan & MF 3 & 460 & 460 & 480 & 520 & 0 \\
$(1 \mathrm{mg})$ & MF 4 & 460 & 460 & 480 & 520 & 0 \\
& MF 5 & 280 & 240 & 460 & 480 & 0 \\
& MF 6 & 480 & 480 & 500 & 540 & 0 \\
\hline
\end{tabular}

\section{Pembahasan}

Karakterisasi dan identifikasi imunoglobulin dari mencit yang diimunisasi dengan protein E selain IgM, IgG ditemukan beberapa subklas imunoglobulin $\mathrm{G}$ antara lain IgG1a, IgG2a, IgG2b. Hal ini seperti vaksin envelope dari dengue yang dikembangkan oleh Smucny et.al. (1995) yang disuntikkan pada anjing laut, dan menemukan imunoglobulin subklase. Imunoglobulin yang ditimbulkan oleh stimulasi protein E yang diimunisasikan menghasilkan titer yang berbeda diantara subklas imunoglobulin G. IgG1a dan IgG2b. Analisa dengan ELISA menunjukkan titer antibodi yang cukup tinggi dan bila dibandingkan dengan subklas lainnya terdapat perbedaan yang signifikan. Hal ini menunjukkan bahwa yang berperan sebagai antibodi yang protektif terhadap infeksi virus dengue adalah IgG1a dan IgG2 $b^{6,7}$ dan juga protein $E$ yang mempunyai korelasi dengan kepekaan sel pada awal infeksi (Anderson, dkk, 1992). Hal ini seperti juga pada vaksin DNA yang dikembangkan oleh Korchel dan Raviprakash. ${ }^{17}$

Profil respon imun humoral secara keseluruhan pada hewan percobaan dapat dilihat pada Gambar 1,2,3. Respon terhadap stimulasi imunoglobulin pada awalnya rendah, namun setelah beberapa hari kadar antibodi semakin meningkat sesuai dengan dosis yang diberikan. Hal ini mungkin karena proses stimulasi sel B untuk produksi imunoglobulin melalui beberapa proses internalisasi pada sel asesoris. Proses ini memerlukan waktu untuk dikomunikasikan dengan sel B dan sel Th dengan cara mengaktifkan sel Th untuk 
sekresi IL-4, 5, 6 dan secara langsung pada sel B karena protein $\mathrm{E}$ rekombinan dapat bertindak sebagai native antigen, sehingga sel B sangat mudah mengadakan endositosis dan selanjutnya dipresentasikan dalam bentuk peptid antigen melalui MHC II; dan diakhiri dengan produksi imunoglobulin protektif yang tinggi.

Analisis respon imun pada CD4 dan CD8 yang diisolasi dari darah hewan percobaan yang telah diimunisasi, direaksikan dengan IFN- $\alpha$ ternyata menunjukkan adanya perbedaan respon imun yang berbeda. Dengan dosis vaksin (konsentrasi protein E/ $\mathrm{ml}$ ) yang berbeda yaitu dosis $1 \mathrm{mg}$ pada monyet menunjukkan daya stimulator terhadap antibodi lebih tinggi dibandingkan dengan dosis vaksin yang mengandung $500 \mu \mathrm{g} / \mathrm{ml}$. Data ini juga didukung oleh titer antibodi pada mencit, tikus dan kelinci, respon antibodi yang terbentuk tergantung dosis yang diimunisasikan, walupun respon imun sedikit berbeda. Hasil ini menunjukkan persamaan dengan vaksin peptid sintetik virus dengue yang dikembangkan oleh Huang, dkk (1999). ${ }^{18}$ Selain itu sitokin yang diekspresi pada dosis $1 \mathrm{mg} / \mathrm{ml} \mathrm{lebih} \mathrm{tinggi} \mathrm{konsentrasinya} \mathrm{dibandingkan}$

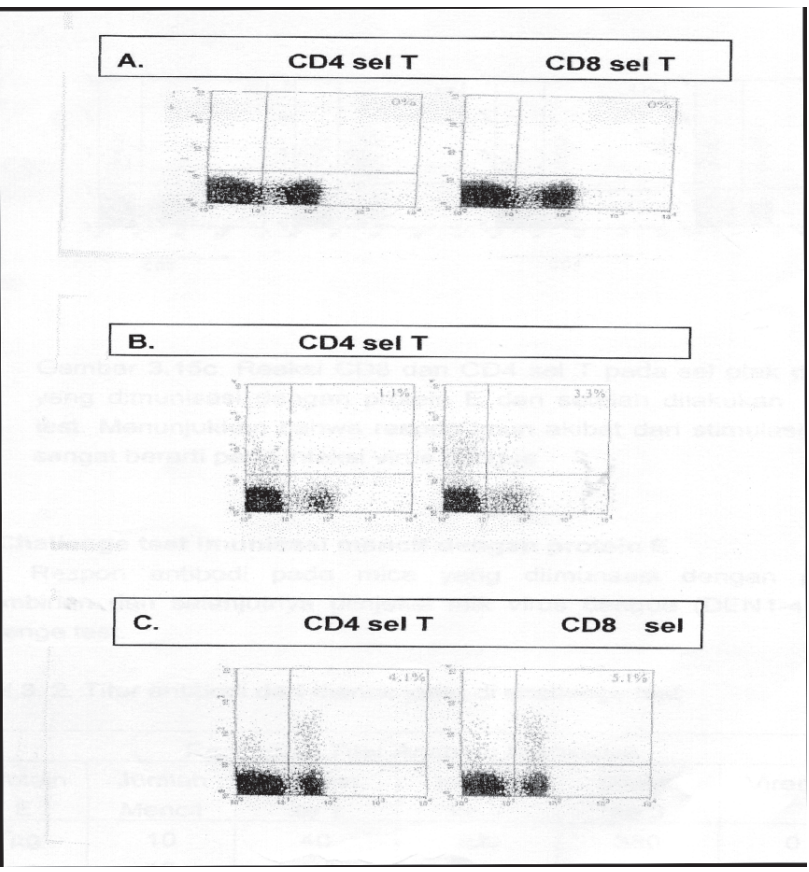

Gambar 2: A) Kontrol negatif dari deteksi spesifik epitope

B) Analisis CD8 dan CD4 sel T super fisial yang direaksikan dengan IFN- $\alpha$

C) Analisis CD8 dan CD4 sel T intra selular yang direaksikan dengan IFN- $\alpha$ dengan dosis $500 \mathrm{mg} / \mathrm{ml}$. Adanya perbedaan ekspresi ini karena berkaitan dengan fungsi sitokin, selain sebagai pemicu reaksi imun terhadap infeksi juga berfungsi sebagai anti infeksi ${ }^{8}$. Walaupun sitokin secara vasoaktif juga di lepas oleh sel mas dan basophil, namun ekspresi sitokin ini merupakan rangkaian dari innate immunity dan adaptive immunity. ${ }^{9,10}$

Pada tahap challenge test semua hewan percobaan secara klinis tidak menunjukkan gejala yang patognomonis terhadap adanya infeksi dengue tetapi pada hewan percobaan monyet memberikan respon patologis yang cukup patognomonis yaitu terlihat adanya perdarahan di daerah yang tidak berbulu 3 hari setelah infeksi. Hal ini terjadi pada kontrol (MF1), sedang pada perlakuan (MF3, MF4, MF5, MF6) tidak tampak gejala spesifik infeksi virus dengue. Hasil ini sesuai dengan fungsi protein $\mathrm{E}$ sebagai imun induksi yang spesifik terhadap respon imun humoral. Pada kelompok hewan percobaan lainnya menunjukkan hasil yang cukup baik walaupun gejala yang spesifik tidak tampak, tetapi secara umum mengalami penurunan. Data ini didukung dengan adanya viremia. Pada kelompok perlakuan yang diimunisasi dengan protein $\mathrm{E}$ rekombinan dan selanjutnya diinfeksi dengan virus campuran virus dengue menunjukkan titer antibodi yang tinggi 1820 . Tingginya titer antibodi ini karena adanya dua sifat dari protein $\mathrm{E}$ yaitu sebagai linear epitope juga discontinous epitope ${ }^{11}$ sehingga antibodi yang timbul dimungkinkan sebagai antibodi neutralisasi, ${ }^{12,13}$ selain itu protein E juga menginduksi sistem imun pada mencit melalui sel asesoris dan lebih terfokus pada proses induksi sel B untuk memproduksi antibodi humoral.

Walaupun tidak semua individu menghasilkan titer antibodi yang sama dan dengan melihat sifat protein

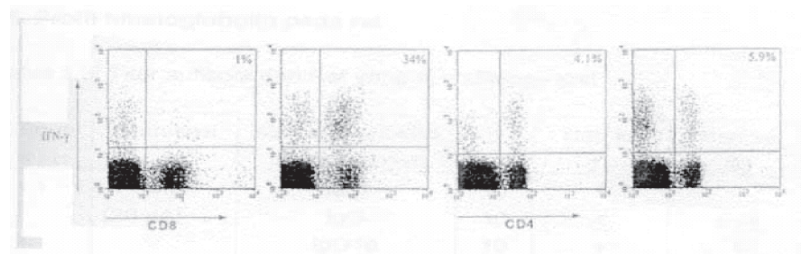

Gambar 3. Reaksi CD8 dan CD4 sel T pada sel otak dari mencit yang diimunisasi dengan protein $\mathrm{E}$ dan setelah dilakukan challenge test. Menunjukkan bahwa respon imun akibat dari stimulasi protein $\mathrm{E}$ sangat berarti pada infeksi virus dengue. 
E yang imunogen, maka hasil ini sangat sesuai untuk menghambat transmisi virus dengue akibat antibodydependent enhancment. ${ }^{14} \mathrm{Hal}$ ini karena setiap individu mempunyai respon imun yang berbeda, akibat dari variabel yang bermacam-macam tingkatannya. Pada hewan percobaan tikus respon imun yang timbul akibat vaksinasi dengan protein E rekombinan menunjukkan titer antibodi yang cukup tinggi dan ditemukan beberapa klas dan subklas imunoglobulin. (Tabel 3). Kelas imunoglobulin yang mempunyai titer antibodi tinggi adalah IgG; sedangkan IgM, IgG1, IgG2a dan IgG2b tidak terlalu tinggi. Hal ini sedikit berbeda dengan mencit IgG2b dan IgG1 mempunyai titer tinggi. ${ }^{15}$ Model hewan percobaan ini sering digunakan eksperimen sebagai kandidat vaksin, walaupun sedikit kurang peka dalam memproduksi antibodi khususnya respon akibat dari infeksi virus dengue.

Respon imun terhadap infeksi virus dengue pada mencit lebih baik dibandingkan dengan tikus. ${ }^{15,16}$ Pada hewan percobaan khususnya untuk eksperimen virus dengue, sampai sekarang belum ditemukan model hewan percobaan yang sesuai. Untuk itu pada tahapan ini dilakukan beberapa model hewan percobaan antara lain kelinci. Respon imun yang timbul pada kelinci yang telah diimunisasi dengan protein E rekombinan virus dengue dan baculovirus tidak ditemukan semua jenis atau klas dan subklas imunoglobulin (Tabel 4); walaupun titer antibodi dari imunoglobulin G lebih dominan dibandingkan dengan subklas lainnya seperti IgG1a, IgG2a dan IgG2b.

Protein E rekombinan yang diimunisasikan pada monyet dapat menginduksi antibodi humoral yang mempunyai titer cukup tinggi terutama imunoglobulin G (Tabel 5). Dari hasil titer antibodi dapat diprediksi respon imun monyet terhadap protein $\mathrm{E}$ terbentuk dengan baik yaitu dalam proses terbentuknya sel memori dari sel B yang memproduksi antibodi. ${ }^{17} \mathrm{Hal}$ ini sesuai dengan sifat protein $\mathrm{E}$ rekombinan yang mempunyai ikatan kovalen dan bersifat hidrofobik yang diregulasikan dalam tubuh melalui sistem imun yang berawal dari fragmen antigen yang diekspresikan oleh MHC II dari sel asesoris atau langsung peda sel B. Dengan demikian antibodi yang terinduksi oleh protein E mempunyai titer tinggi.

Tingginya titer antibodi dari hewan percobaan yang diimunisasi dengan protein E rekombinan cukup positif hal ini sebagai dasar untuk proses pencarian kandidat vaksin dengan hasil yang optimal, dan antibodi yang ditimbulkan bersifat protektif. ${ }^{18}$ Pada tahapan selanjutnya masih diperlukan tes protektifitas pada hewan percobaan dengan challenge test.

Pada penelitian ini penggunaan protein E rekombinan sebagai kandidat vaksin sangat representatif karena protein $\mathrm{E}$ merupakan soluble antigen, untuk stimulasi sel $\mathrm{T}$ melalui sel asesori sebagai antigen sel presenting yang mengekspresikan antigen peptida dari protein $\mathrm{E}$ melalui MHC II, selain itu antigen sel presenting ikut bertanggung jawab dalam produksi antibodi spesifik dengue melalui native antigen maupun melalui Th2 dengan cara mensekresi interleukin 4 atau CD 40 dan ligan. Dan yang teristimewa adalah tidak diperlukan dosis yang tinggi. Hal ini didukung oleh Reviprakash dkk. ${ }^{5}$ (2000). Walaupun protein E menginduksi kedua sistem imun humoral dan seluler, namun target utamanya adalah respon imun humoral. Sehingga kemungkinan terjadinya reaksi hipersentivitas dapat dikesampingkan.

Pada tahap challenge test yang yang dilakukan pada monyet sedikit berbeda dengan kelompok lainnya. Hal ini bertujuan agar didapatkan model yang komprehensif, sehingga dapat menampakkan gejala yang simptomatis seperti yang terjadi infeksi dengue pada manusia. Tahap awal kelompok perlakuan diimunisasi dengan protein E rekombinan, 28 hari setelah booster diinfeksi campuran virus dengue DEN 1-4, yang mempunyai titer rendah. Kemudian setelah 21 hari di infeksi dengan DEN-1. Sedang pada kelompok kontrol tanpa diberi imunisasi, ternyata gejala yang timbul sangat signifikan dan patognomonis. Hasil ini kemungkinan berkaitan dengan reaksi respon imun yang abnormal yang sesuai dengan teori dependent enhancement yang memberikan peluang virus untuk menginfeksi sel mono-nuklear melalui komplek imun antara virus, antibodi yang tidak protektif dan sel monosit.

\section{Kesimpulan}

Hasil penelitian ini, maka dapat disimpulkan bahwa,

1. Telah didapatkan protein $\mathrm{E}$ rekombinan murni yang mempunyai reaktivitas yang tinggi terhadap antibodi poliklonal. Protein E yang didapat mempunyai daya imunogenik yang cukup tinggi dan mampu menetralisasi infeksi virus dengue pada hewan percobaan, mencit, tikus, kelinci dan monyet.

2. Protein E pada hewan percobaan dapat meng- 
induksi antibodi humoral dengan berbagai kelas (IgM, IgG) imunoglobulin maupun subkelas (IgG, IgG1a, IgG2a, IgG2b) dan selular yang protektif.

3. Protein E rekombinan tidak menginduksi adanya reaksi hipersensivitas pada semua tipe.

4. Gejala DBD yang patognomonis ditemukan pada monyet kelompok kontrol yang disuntik dengan virus dengue dari semua galur yang dapat diisolasi di Indonesia.

5. Protein E rekombinan mempunyai sifat yang stabil dan imunogen yang dapat menginduksi antibodi humoral dengan titer yang tinggi dan protektif.

\section{Saran}

Perlu dikaji terjadinya kekebalan jangka panjang lebih dari 10-15 tahun, yang ditimbulkan oleh protein $\mathrm{E}$ rekombinan dengan dosis yang optimal.

\section{Daftar Pustaka}

1. Sumarmo. Penatalaksanaan Demam Berdarah Dengue. Medika Jakarta.1989; 2:16.

2. Suchitra Nimmanitya. Management of Dengue and Haemorrhagic Fever. Monograph on Dengue/Dengue Haemorrhagic Fever. WHO. Regional Publication Searo. New Delhi No. 22;1993.

3. Thomas Suroso. Perkembangan demam berdarah dengue di Indonesia. Disampaikan pada Seminar Demam Berdarah Dengue. Jakarta, 8 Juni 1991.

4. Rigau-Perez, J.G; Clark, G.G; Dubler, D.J; Reiter, P; Sanders, E.J; Vorndam, A.V. dengue and dengue haemorrhagic fever. Lancet 1998; 352:971-77.

5. Raviprakash, K; Porter, K.R; Kochel, T.J; Ewing, D; Simmons, M; Phillips, I; Murphy, G.S; Weiss, W.R and Hayes, C.G. Dengue virus type 1 DNA vaccine induces protective immune responses in rhesus macaques. Virol 2000; 81:1659-67.

6. Men, R; Wyatt, L; Tokimatsu, I; Arakaki, S; Shameem, G; Elkins, R; Chanock, R; Moss, B and Lai, C.J. Immunization of rhesus monkeys with a recombinant of modified vaccinia virus Ankara expressing a truncated envelope glycoprotein of dengue type 2 virus induced resistance to dengue type 2 virus challenge. Vaccine 2000; $18: 3113-3122$
7. Most, R.G; Krisnha, K.M; Ahmed, R; Strauss, J.H Chimeric yellow fever/dengue virus as a candidate dengue vaccine: quantitation of the dengue virus-specific CD8 T-cell response. Virol 2000; 74:8094-8101.

8. Guidotti, L.G and Chisari, F.V. Cytokine-Mediated control of viral infections. Virology, 2000; 273:221-7.

9. Estcourt, M.J; Ramshaw, I.A; Ramsay, A.J. Cytokine response in virus infections effect on pathogenesis, recovery and persistence. Curr. Opin. Microbiol 1998; 4:411-18.

10. Karupiah, G; Blanden, R.V; Ramshaw, I.A. Interferon gamma is involved in the recovery of athymic nude mice from recombinant vaccinia virus/interleukin 2 infection. J. Exp. Med. 1990; 172:1495-502.

11. Megret, F; Hugnot, P.J, Falconar, A; Gentry, M.K, Morens, D.M; Regenmortel, M.H.V; Deuble, V. Use of recombinant fusion proteins and monoclonal antibodies to difine linear and discontinous antigenic site on the dengue envelope glycoprotein. Virology 1992; 187:480-91.

12. Sataropoli, I; Clement, J.M; Frenkiel, M.P; Hofnung, $\mathrm{M}$ and Deuble, V. Dengue-1 virus envelope glycoprotein gene expressed in recombinant baculovirus elicits virus neutralization antibody in mice and protects them from virus challenge. Am. J. Trop. Med. Hyg 1996; 45:159-67.

13. Sataropoli, I; Frenkiel, M-P; Mergret, F and Deuble, V. Affinity-purified dengue-2 virus envelope glycoprotein induces neutralizing antibodies and protective immunity in mice. Vaccine 1997; 15:1-9.

14. Ferguson, N; Anderson, R and Gupta, S. The effect of antibody-dependent enhancement on the transmission dynamics and persistence of multiple-strain pathogens. Issue 1999; 2:790-4.

15. Pletnev, A.G; Karganova, G.G; Dzhivanyan, T.I; Lashkevich, V.A and Micheal Bray. Chimeric Langat/ Dengue Viruses protect mice from heterologous challenge with the highly virulent strains of tick-born encephalitis virus. Virology 2000; 274:26-31.

16. Rantam, F.A; Soetjipto; Sudiana, I.K. Profil antibodi humoral dan seluler pada tikus yang diimunisasi protein E rekombinan, J. Vet. Med. 2001; 17:89-94.

17. Kochel, T.J; Raviprakash, K; Hayes, C.G; Watts, D.M; Russell, K.L; Gozalo, A.S; Phillips, I.A; Ewing, D.F; Murphy, G.S and Porter, K.R. A dengue virus serotype1 DNA vaccine induces virus neutralizing antibodies and provides protection from viral challenge in Aotus monkeys. Vaccine 2000; 18:3166-73.

18. Huang, JH, Wey, JJ, Sun, J.C, Chin, C, Chien, LJ, Wu, YC. Antibody response to an immunodominant non structural 1 synthetic peptide in patients with dengue fever and dengue haemorrhagic fever. Med Virology 1999; 57:1-8. 